\title{
Molecular Armory of S. Typhi: Deciphering the Putative Arsenal of Our Enemy
}

\author{
Chantal G. Forest and France Daigle \\ Department of Microbiology E Immunology/University of Montreal
}

Canada

\section{Introduction}

The outer surface of bacteria is the first to interact with host components, such as the immune system, the extracellular matrix or cells. The bacterial Gram-negative cell wall is complex and composed of an inner membrane (IM), a periplasmic space and a thin peptidoglycan layer, all surrounded by an outer membrane (OM). The OM is a bilayered structure consisting mainly of phospholipids, proteins and lipopolysaccharide (LPS) and serves as an impermeable barrier to prevent the escape of periplasmic molecules but also acts as a barrier for entry of external molecules. Salmonella enterica comprises more than 2500 serovars, based on three major antigens located at the cell surface: $\mathrm{O}$ antigen, capsule and flagella. All serovars are highly conserved genetically but have different host ranges and cause different diseases. In humans, Salmonella infection causes gastroenteritis, often associated with serovars Typhimurium and Enteritidis or typhoid-like disease, which is associated with serovars Typhi and Paratyphi. S. Typhi strains belong to serogroup D1 with the antigenic formula $\mathrm{O}: 9,12 ; \mathrm{Vi}+; \mathrm{H}-\mathrm{d}$. These strains are human-restricted and besides asymptomatic carriers, no environmental reservoir is known.

S. Typhi is a monomorphic bacterium, showing very little genetic diversity (Kidgell et al., 2002) and up to $5 \%$ of its annotated coding sequences are pseudogenes (Holt et al., 2009; Parkhill et al., 2001). Genome degradation may be responsible for its host specificity; however the $S$. Typhi genome may harbour specific genes for its systemic dispersion and survival. $S$. Typhi remains a major public health problem in developing countries. Antimicrobial resistance has become a problem in endemic regions, and it is becoming imperative to develop new vaccine strategies or discover new antimicrobial targets to combat this microorganism. Bacterial surface proteins may correspond to these targets by being immunogenic or essential for virulence. Most virulence factors are usually located within genomic locations called Salmonella Pathogenicity Islands (SPIs) and are tightly regulated by global regulators such as PhoP-PhoQ, RcsDBC, OmpR-EnvZ and RpoS. This review will focus on molecules localized at the outer membrane of $S$. Typhi and their role in pathogenesis. A complete analysis of adhesive molecules, such as the 12 fimbrial systems, curli, type IVB pilus, autotransporters and afimbrial adhesins will be presented. We will also discuss the importance of polysaccharides such as the Vi capsule and LPS. Furthermore, the complex surface structures generated by secretion systems, such as type three secretion systems (T3SS), flagella and T6SS that are so important for invasion, intracellular survival and to highjack the host defence system will be discussed. Finally, methods used to inhibit these adhesive structures will be described. 


\section{Fimbrial adhesins}

Fimbriae (also called pili) are proteinaceous structures that can be observed as filaments anchored on the bacterial cell surface. These structures can mediate crucial interactions during host infection like adherence, invasion or biofilm formation, and are classified according to their mechanism of assembly. Most of the fimbriae present in S. Typhi genome are assembled by the chaperone/usher pathway, but there are also one representative of the nucleation/precipitation pathway (csg) and one type IVB pilus. This section will briefly describe each mechanism of expression and the current knowledge related to S. Typhi and their putative roles.

\subsection{Mechanisms of fimbrial assembly}

\subsubsection{The chaperone/usher pathway}

Twelve fimbrial systems detected in S. Typhi belong to the chaperone/usher pathway (CUP) assembly class (Fig. 1). A classic fimbrial operon usually harbours at least four different genes. The filaments are composed of major and minor fimbrial subunits assembled by the cooperative work of the chaperone and the usher. After translocation by

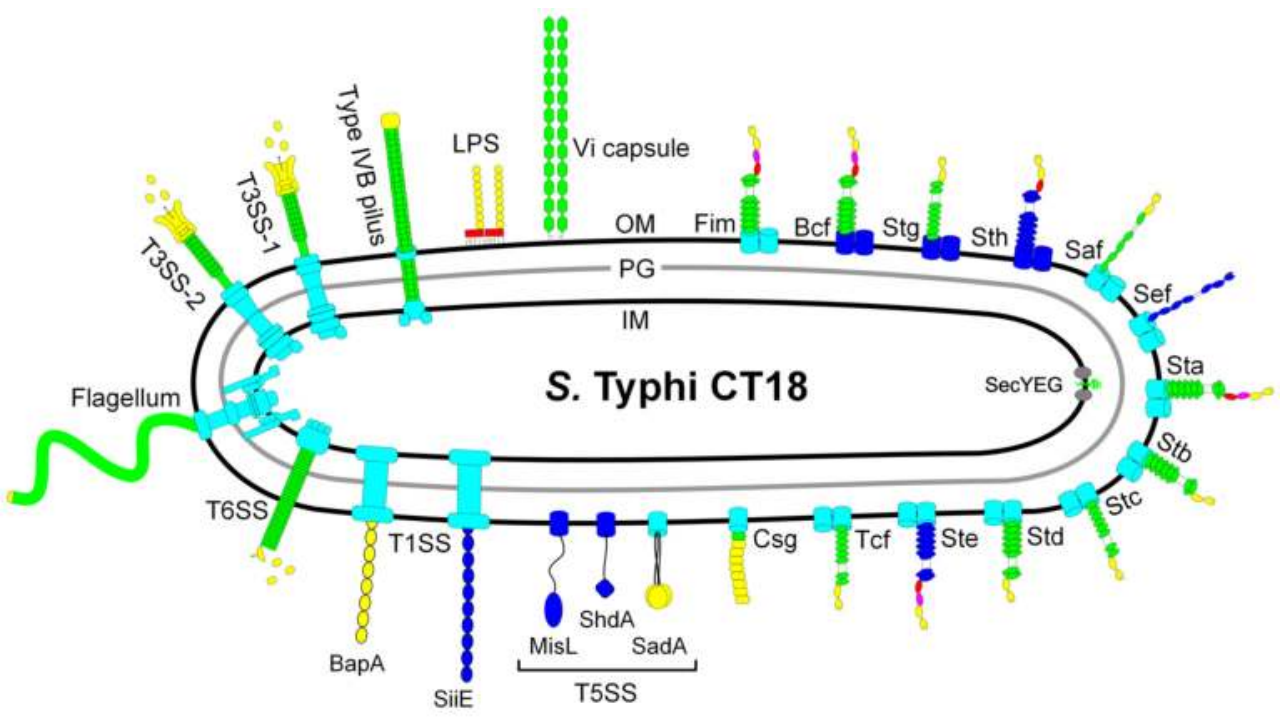

Fig. 1. Schematic representation of the important surface structures identified in S. Typhi CT18. Adhesive components are shown in yellow, membrane components are cyan and pseudogenes are shown in blue (pseudogenes of the T6SS are not shown). The twelve representatives of the CUP are grouped in fimbrial clades and are drawn according to previous observations (Salih et al., 2008) or based on their homologues found in E. coli K-12 (Korea et al., 2011). STY0405 putative autotransporter, STY0351 adhesin, and PagC which are known to be implicated in virulence were omitted from the drawing, as well as STY1980 (MAM7). IM stands for inner membrane, PG for peptidoglycan and OM for outer membrane. 
the Sec general secretory pathway, the periplasmic chaperone protects the subunits and brings them to the OM usher, which specifically translocates subunits to the cell surface. Fimbrial biogenesis by the CUP pathway is a self-energized process catalyzed by both the usher and the presence of high-energy intermediates in the folding of the chaperone-subunit complexes (Jacob-Dubuisson et al., 1994; Nishiyama et al., 2008; Sauer et al., 2002; Zavialov et al., 2002). Classification based upon sequence homology between the different ushers (Nuccio \& Bäumler, 2007) revealed members in the $\gamma^{1-}$ (bcf, fim, stg, sth), $\gamma^{3}$ - (saf, sef), ү4- (sta, $s t b, s t c), \Pi-(s t d, s t e)$ and the a-fimbrial clades (tcf) in S. Typhi (Fig. 1).

\subsubsection{Nucleation/precipitation pathway}

The thin aggregative fimbriae, also known as curli or TAFI, encoded by the $\operatorname{csg} D E F G \operatorname{csg} A B C$ gene cluster belongs to this class of adhesin. The first steps of biogenesis are similar to the CUP : after translocation by the Sec pathway, CsgA and CsgB fimbrial subunits are secreted by the CsgG outer membrane protein at the bacterial cell surface. The major difference between curli and CUP lies in its extracellular fiber growth assembly (Hammar et al., 1996). After secretion of the CsgB subunit, CsgA precipitates, polymerizes on CsgB and adopts an insoluble structure related to amyloid fibers (Hammar et al., 1996).

\subsubsection{Type IVB pili}

One of the most studied adhesive structures of $S$. Typhi is the type IVB pilus encoded by the pil operon located on SPI-7. Although type IV pili also produce long and flexible structures on the bacterial cell surface, their mechanism of assembly strongly differs from the CUP and curli pathways as it requires many structural proteins and is an ATPdependent process. First, PilS prepilins are translocated through the IM into the periplasm and a specific prepilin peptidase cleaves the N-terminal signal peptide (reviewed in Craig $\& \mathrm{Li}, 2008)$. An integral IM protein mobilizes a specific ATPase from the cytoplasm which drives pilus assembly. An oligomeric channel called the secretin found in the OM allows the exit of the pilus at the cell surface of the bacteria. ATP hydrolysis moves the pilus out in the secretin pore allowing the recruitment of new prepilin subunits. Unlike CUP and Csg fimbriae, Type IV pili are still connected to the IM of the bacteria and can be retracted rapidly inside the bacteria.

\subsection{Roles of fimbrial adhesins during typhoid fever}

In most studies, Salmonella fimbriae are involved during intestinal colonization (Althouse et al., 2003; Chessa et al., 2009; Weening et al., 2005), or in biofilm formation (Boddicker et al., 2002; Ledeboer et al., 2006), although they can also be used during the systemic phase (Edwards et al., 2000; Lawley et al., 2006). Interestingly, each serovar of Salmonella enterica harbours a unique combination of fimbrial operons, probably to avoid cross-immunity between two serovars infecting the same host (Norris \& Bäumler, 1999; Nuccio et al., 2011). As $S$. Typhi infects only humans, little is known regarding the conditions of expression or the implication of each fimbrial adhesin during the course of infection. While some clues may be found in the literature, there is still much work to be done. Three fimbrial systems are clustered within pathogenic islands: tcf (Typhi colonizing factor) and saf (Salmonella atypical fimbriae) are found within SPI-6, while sef is in SPI-10 (Sabbagh et al., 2010). 
Proteins expressed during infection were detected in blood of patients with typhoid fever (Charles et al., 2010; Harris et al., 2006; Hu et al., 2009). Interestingly, six proteins related to fimbrial adhesins led to the formation of antibodies after typhoid fever (TcfB, StbD, CsgG, $\mathrm{CsgF}, \mathrm{CsgE}$ and BcfD). Since three proteins belonging to the thin aggregative fimbriae were identified, it suggests a strong production in vivo as well as an important role during infection. Csg implication during attachment to surfaces, bacterial autoaggregation and in biofilm formation is well known for S. Typhimurium and E. coli (Jonas et al., 2007). Nevertheless, a clear characterization of $c s g$ is needed for $S$. Typhi as there seem to be variations in expression between the different isolates (Römling et al., 2003; White et al., 2006). In S. Typhi, a strong expression of csg and saf fimbrial operons was observed inside human macrophages (Faucher et al., 2006).

The $b c f$, sef, ste, stg and sth fimbrial systems harbour pseudogenes that might disrupt the production of the corresponding fimbriae (Townsend et al., 2001). However, deletion of stg leads to reduced adhesion on epithelial cells as well as enhancement of the phagocytosis rate by macrophages (Forest et al., 2007). Furthermore, the presence of antibodies directed against $\mathrm{BcfD}$ is intriguing since the $b c f C$ usher harbours two premature stop codons (Parkhill et al., 2001). The Bcf, Stb, Stc, Std and Sth fimbrial systems are required for the intestinal persistence of $S$. Typhimurium in mice, but their roles during the pathogenesis of $S$. Typhi still need to be evaluated (Weening et al., 2005). Sta and Tcf do not seem to be used for adhesion or invasion of non-polarized human epithelial cells while both are expressed at high $\mathrm{NaCl}$ concentrations (Bishop et al., 2008). Since these two fimbriae are found almost exclusively in the genome of serovars causing typhoid fever, they might be involved during the systemic phase or for the chronic carrier state (Nuccio et al., 2011). Although roles for Saf (Carnell et al., 2007; Lawley et al., 2006), Sef (Edwards et al., 2000) and Std fimbriae (Chessa et al., 2008; Weening et al., 2005) have been observed in other serovars of Salmonella, their true implication during typhoid fever needs to be investigated.

Type 1 fimbriae encoded by the fim operon are the best studied fimbrial adhesins and are frequently found in enteric bacteria. Fim are characterized by their mannose-sensitive binding properties, but their cell tropism seems to vary greatly between species and even between different strains of the same serovar (Thankavel et al., 1999). In S. Typhi, most clinical strains are fimbriated $\left(\right.$ fim $\left.^{+}\right)$and afimbriated strains are less adhesive and invasive than the fimbriated ones (Duguid et al., 1966; Satta et al., 1993). The ability of type 1 fimbriae to agglutinate yeast is abolished when the Vi capsule is expressed (Miyake et al., 1998). In S. Typhimurium, Fim appears to be the only fimbrial adhesin expressed in Luria-Bertani (LB) broth as confirmed by electron microscopy and flow cytometry (Duguid et al., 1966; Humphries et al., 2003). In S. Typhi, a complete deletion of fim also showed no evident fimbrial structures on the cell surface of the bacteria after growth in LB broth (Fig. 2).

Type IVB pili interact with the cystic fibrosis transmembrane conductance regulator (CFTR), a receptor upregulated and actively used by $S$. Typhi for its interaction with human epithelial cells (Lyczak \& Pier, 2002; Pier et al., 1998; Tsui et al., 2003). These pili can also mediate bacterial self-association in conditions found in the intestinal tract, probably by enhancing binding efficiency prior to cell invasion (Morris et al., 2003a; Morris et al., 2003b). A direct correlation was observed between the level of surface-exposed CFTR and the efficiency of invasion of S. Typhi through the intestinal barrier (Pier et al., 1998). This specific interaction can be blocked by the addition of prepilin pre-PilS in the cell culture medium or with monoclonal antibodies specific to the first extracellular domain of CFTR 
(Pier et al., 1998; Zhang et al., 2000). A piliated strain also adheres and invades human monocytes in a greater extent than a non-piliated strain and its expression can also increase IL-6 and NF-kappa B production in human monocytes by activating protein kinase C (Pan et al., 2005; F. Wang et al., 2005). Only a few other serovars, such as S. Paratyphi B and C, S. Heidelberg and $S$. bongori possess the genetic information coding for type IVB pili (Nuccio et al., 2011). Other functions could potentially be found in future studies as Type IV pili are also implicated in a variety of processes like biofilm formation, immune escape, DNA uptake and phage transduction in other pathogenic bacteria (reviewed in Craig \& Li, 2008). These pili can also act as pistons, retracting subunits into the bacteria while it is still attached to a surface in a mechanism called "twitching motility" providing flagella-independent motility (reviewed in Mattick, 2002).
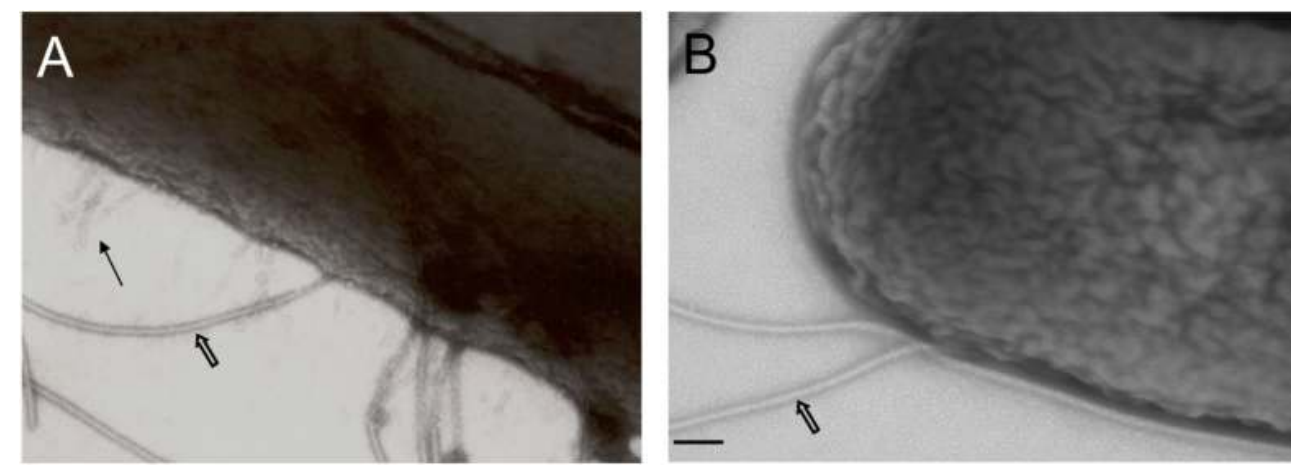

Fig. 2. Surface observation of $S$. Typhi grown in LB broth by transmission electron microscopy. After negative staining with phosphotungstate $1 \%$, fimbriae were observed at the cell surface of the wild-type ISP1820 strain (A), while no structure was observed when fim was deleted (B). Black arrow shows fimbria and the open arrows indicate flagella. Black bar $=100 \mathrm{~nm}$.

No genes related to fimbrial operons were found after a screening for mutants with a competitive disadvantage in humanized mice engrafted with hematopoietic stem cells (Libby et al., 2010). This result strongly suggests that fimbrial operons are mostly required during interaction with human epithelial cells, such as intestinal and gallbladder cells, that are absent from this mice model. Moreover, functional redundancy is often observed for fimbrial adhesins making it hard to evaluate their true contribution by single mutations. In order to understand the specific role played by each fimbrial system, our laboratory is currently creating a $S$. Typhi strain with deletions of all its fimbrial adhesins. This strain will greatly help to evaluate the global contribution of each fimbrial adhesins during association with eukaryotic cells.

\section{Non fimbrial adhesins}

\subsection{Type 1 secretion systems}

In Salmonella, some important surface structures are expressed by different mechanisms and can be classified as non fimbrial adhesins. In $S$. Typhi, there are two examples of adhesins secreted by a type I secretion system (T1SS) : SiiE and BapA. In T1SS, the secreted proteins 
directly pass through a channel formed between the IM and $\mathrm{OM}$ of the bacteria by the recognition of a signal at the C-terminus (China \& Goffaux, 1999 as cited in Main-Hester et al., 2008). SPI-4, present in all Salmonella strains, encodes a T1SS responsible for the secretion of SiiE, the largest protein found in Salmonella (595 kDa) (Latasa et al., 2005; Main-Hester et al., 2008). Its cell surface expression requires the IM ATPase SiiF, the periplasmic adaptor SiiD and an outer membrane channel formed by SiiC (Gerlach et al., 2007). This adhesion system acts in a coordinated way with the T3SS of SPI-1 and is involved during the intestinal phase of infection (Gerlach et al., 2008). Previously annotated as two distinct ORFs in S. Typhi (STY4458-4459) (Parkhill et al., 2001), siiE harbours a premature stop codon probably rendering this large adhesin non-functional (Main-Hester et al., 2008; Morgan et al., 2004). An immunoblot done with antibodies directed against SiiE (STY4458) demonstrated the absence of production of SiiE in the whole cell proteins of $S$. Typhi further suggesting a lack of function in this serovar (Main-Hester et al., 2008). However, a transposon insertion in STY4458 showed a reduced competitive fitness in humanized mice, suggesting SiiE functionality and an uncharacterized role during interaction with hematopoietic cells (Libby et al., 2010).

A second T1SS is clustered within SPI-9 and secretes another large repetitive protein called BapA (biofilm-associated protein) due to its similarity with BapA of Staphylococcus aureus. Well described in S. Enteritidis, BapA is involved in bacterial autoaggregation strongly inducing biofilm formation and is also required during the interaction with the intestinal mucosa (Latasa et al., 2005). Its expression is under the control of CsgD, an important regulator also coordinating curli fimbriae and cellulose production needed for biofilm production (Jonas et al., 2007). Again, solving the components required for biofilm formation by $S$. Typhi is crucial since $b c s C$ (STY4184), essential for cellulose and biofilm production, is a pseudogene (Parkhill et al., 2001; Zogaj et al., 2001).

\subsection{Type 5 secretion systems}

Autotransported adhesins can be monomeric or trimeric and are considered as type 5 secretion systems. S. Typhi harbours two monomeric examples of autotransported adhesins, shdA (STY2755) found in the CS54 island and misL (STY4030) clustered in SPI-3, as well as one representative of a trimeric autotransporter called sadA (STY4105). An N-terminal signal sequence allows their translocation into the periplasm by the Sec general secretory pathway, then a $\beta$-domain found at the $C$-terminal end of the protein adopts a $\beta$-barrel conformation in the OM allowing secretion of the passenger domain into the extracellular space (reviewed in Nishimura et al., 2010). ShdA is widely distributed in S. enterica subspecies I and appears to be produced during typhoid fever despite the presence of a frameshifting sequence (Harris et al., 2006; Parkhill et al., 2001). Interestingly, ShdA and MisL can bind fibronectin in other serovars of Salmonella and are both considered as pseudogenes in S. Typhi (Dorsey et al., 2005; Kingsley et al., 2002). SadA harbours homology to the trimeric autotransporter adhesin YadA of Yersinia enterocolitica, a highly repetitive fibrous surface protein (Grosskinsky et al., 2007). YaiU (STY0405) encodes a fourth putative autotransported adhesin with no known role except that antibodies against the protein are produced during a typhoid fever (Harris et al., 2006).

\subsection{Other adhesins}

Besides fimbrial and afimbrial adhesins, other surface-exposed proteins can act as adhesins and mediate crucial roles during typhoid fever. One of the most hydrophobic proteins 
encoded in the S. Typhi chromosome, STY0351, was recently characterized in detail and might be used as a potential vaccine target. This cell-surface protein is a novel adhesin directly involved in the pathogenesis of $S$. Typhi by conferring strong binding to the laminin extracellular matrix (Ghosh et al., 2011) and is positively regulated by the PhoP-PhoQ twocomponent system (Charles et al., 2009). It also possesses high immunogenic properties and STY0351-specific antibodies confer protection in a mouse model (Charles et al., 2010; Ghosh et al., 2011). PagC is another surface-exposed protein activated by the PhoP-PhoQ system that is produced and actively recognised by antibodies from patients having previously suffered from typhoid fever (Charles et al., 2010; Harris et al., 2006). Previously associated with survival within macrophages (Miller et al., 1989), PagC possesses serum resistance activity (Nishio et al., 2005) and can promote OM vesicle release in S. Typhimurium (Kitagawa et al., 2010), but none of these roles are confirmed yet for S. Typhi.

Multivalent adhesion molecules (MAM) are outer membrane proteins harbouring 6 or 7 mammalian cell entry domains and are widely found in pathogenic Gram-negative bacteria (Krachler et al., 2011). MAM mediates early interactions with different cell types by providing protein as well as lipid interactions with fibronectin and phosphatidic acid (Krachler et al., 2011). The specificity for certain cell types is thought to be provided by the other adhesins clustered throughout the genome of the bacteria. In S. Typhi, BLASTP analysis revealed that STY1980 harbours about 96\% homology with MAM7 of the EPEC strain E. coli O127:H6 (Altschul et al., 1990) and could be implicated during the primary interactions with the intestinal mucosa.

\section{Capsule and LPS}

$S$. Typhi produces a group 1 exopolysaccharide known as the Vi antigen. Thus, S. Typhi is one of the few Salmonella serovars that get shielded by an extracellular polysaccharide layer constituting the Vi capsule. The Vi polysaccharide is a linear homopolymer of $\alpha(1 \rightarrow 4)-2-$ acetamido-3-O-acetyl-2-deoxy-a-D-galacturonic acid (Heyns et al., 1959) and constitutes the major component of an injectable conjugated vaccine presently used against typhoid fever world-wide (World Health Organization, 2003). Vi has been involved in pathogenicity by evading the host innate immune system as it protects bacteria from phagocytosis and complement-mediated killing (Kossack et al., 1981). The in vitro masking of the OAg by the Vi antigen has been known for a long time (Felix \& Pitt, 1934 as cited in Robbins \& Robbins, 1984), prevents recognition by TLR-4, and limited C3 deposition to the cell surface (Looney \& Steigbigel, 1986), which will lead to reduced clearance of the bacteria (Wilson et al., 2011). $\mathrm{Vi}$ is preferentially expressed at low osmolarity and early during infection of human macrophages or mice and will be downregulated with the progression of infection (Daigle et al., 2001; Faucher et al., 2006; Janis et al., 2011). The expression of Vi reduces invasion, probably by limiting the access of the T3SS-1 (Arricau et al., 1998; L. Zhao et al., 2001) or by masking other adhesion molecules including Fim. Vi is also important for surviving in macrophages (Hirose et al., 1997). Vi is tightly regulated by its own activator TviA (Hashimoto et al., 1996; Virlogeux et al., 1996), the two-component system OmpR-EnvZ (Pickard et al., 1994), the Rcs system (Arricau et al., 1998; Virlogeux et al., 1996) and repressed by RpoS (Santander et al., 2007).

Lipopolysaccharide (LPS) is the principal component of the outer membrane of Gramnegative bacteria and a major virulence determinant of many pathogens (Raetz \& Whitfield, 
2002). It is a glycolipid consisting in three structural regions covalently linked: (i) lipid A, also known as endotoxin, a hydrophobic anchor composed of acyl chains linked to phosphorylated $\mathrm{N}$-acetylglucosamine; (ii) the inner and outer core composed of conserved oligosaccharides and; (iii) a variable polysaccharide chain or OAg. Salmonella OAg exhibits extensive composition and structural variation and has been divided into $46 \mathrm{O}$ serogroups (Popoff et al., 2001). The O9 antigen of $S$. Typhi is characterized by the presence of a tyvelose residue. In response to acidified macrophage phagosomes, genes activated by the PhoPPhoQ and PmrA-PmrB systems can modify the global structure of LPS and protect Salmonella from being killed by the immune system, notably by antimicrobial peptides (reviewed in Gunn, 2008). Heterogeneity in the length of the OAg repeats has been observed (P. Reeves, 1993) and is important for serum resistance and interaction with host cells (Bravo et al., 2011; Hoare et al., 2006; Hölzer et al., 2009). The S. Typhi OAg is essential for serum resistance but is not required for cell invasion (Hoare et al., 2006). Internalization of $S$. Typhi by epithelial cells involves the LPS core (Hoare et al., 2006) which acts as a ligand for CFTR (Lyczak et al., 2001; Pier et al., 1998). The S. Typhi LPS core is involved in intracellular replication in macrophages (unpublished data), as observed with $S$. Typhimurium (Nagy et al., 2006; Zenk et al., 2009). S. Typhi does not have a bimodal distribution of OAg as it cannot produce very long OAg, consisting of more than 100 repeats of OAg units, because the major regulator Wzz (FepE) is non functional (Raetz \& Whitfield, 2002). LPS biosynthesis involves many genes located in different clusters on the chromosome and may be controlled through several regulatory systems (P.R. Reeves et al., 1996). In S. Typhi, OAg expression is regulated by $\mathrm{RfaH}$ under the control of sigma factor RpoN (Bittner et al., 2002).

\section{Secretion systems}

\subsection{Type 3 secretion systems}

S. enterica harbours two distinct type 3 secretion systems (T3SSs) located on SPI-1 (T3SS-1) and SPI-2 (T3SS-2) that are crucial to its virulence along with a flagellar apparatus. T3SSs are complex molecular machines built from more than 20 different proteins, forming a structure similar to a molecular syringe (Kubori et al., 1998, Kimbrough \& Miller, 2000 as cited in Sanowar et al., 2010). IM and OM rings are connected by a channel called the needle complex. These structures can inject many protein effectors directly from the bacterial cytoplasm to the cytoplasm of the eukaryotic cells, allowing a direct manipulation of host cellular pathways. The injection process is energized by specific cytoplasmic ATPase and direct contact with the eukaryotic cells is needed in order to activate secretion. Although T3SS are surface-exposed molecules, the lack of specific antibodies against the T3SS in the sera of convalescent patients of typhoid fever (Charles et al., 2010; Harris et al., 2006; Hu et al., 2009) might be a consequence of their tight regulation.

\subsubsection{T3SS-1}

In order to cause a systemic infection, Salmonella must first cross the intestinal epithelial barrier. Conditions found in the intestine, such as low oxygen tension and high osmolarity, are known to induce T3SS-1 of Salmonella by the HilA central regulator (Bajaj et al., 1996, Galán \& Curtiss, 1990 and Jones \& Falkow, 1994 as cited in Altier, 2005). Injection of effectors secreted by the T3SS-1 mediates the invasion of non-phagocytic epithelial cells by Salmonella (Galán \& Curtiss, 1989; Galán, 1999). Effectors interact with the actin cytoskeleton 
and induce membrane ruffles around the bacteria allowing its internalisation into epithelial cells. In $S$. Typhi, the contribution of the T3SS-1 during invasion of epithelial cells was confirmed with invA, sipEBCDA or iagAB (hilAB) mutants (Galán \& Curtiss, 1991; Hermant et al., 1995; Miras et al., 1995). The T3SS-1 of $S$. Typhi may also play a role during the systemic phase of the infection (Haraga et al., 2008; Libby et al., 2010).

\subsubsection{T3SS-2}

After reaching the epithelial submucosa, Salmonella encounters and enters immune system cells like macrophages, dendritic cells and neutrophils. The intracellular environment of these cells promotes induction of the T3SS-2, which is regulated by the SsrA-SsrB two-component regulatory system. Inside cells, bacteria are found in a SCV (Salmonella-containing vacuole) and inject T3SS-2 effectors to modify the SCV, alter host pathways and promote intracellular survival (Brumell et al., 2001; Waterman \& Holden, 2003; Yu et al., 2004). Although S. Typhimurium absolutely requires the T3SS-2 for its intramacrophage survival (Cirillo et al., 1998; Hensel et al., 1998), a complete deletion of this system does not impair survival of $S$. Typhi in human macrophages (Forest et al., 2010). Nevertheless, S. Typhi T3SS-2 might be required for survival in other immune cells, as a mutant harbouring a transposon insertion in ssrB is disadvantaged in a humanized mouse model (Libby et al., 2010).

\subsubsection{Flagella}

The flagellar apparatus constitutes a third T3SS that is under the control of a highly organized transcriptional hierarchy involving three promoter classes with $f h D C$ being the first activator (Kutsukake et al., 1990 and Karlinsey et al., 2000 as cited in Chevance \& Hughes, 2008). In Salmonella, each cell harbours 6-8 peritrichous flagella built from more than 25 different proteins (Harshey, 2011). The final structure is composed of a basal body, including a stationary and a moving rotor, an external hook and the filament comprised of flagellin (Harshey, 2011). Secretion of flagellin subunits and motility processes are powered by the proton motive force (Minamino \& Namba, 2008 and Paul et al., 2008 as cited in Chevance \& Hughes, 2008). Subspecies I, II, IIIa and IV of Salmonella enterica are considered biphasic since they can alternatively express FliC or FljB major flagellar subunits in a mechanism known as phase variation (Lederberg \& Iino, 1956; Simon et al., 1980). Most $S$. Typhi strains do not possess the $f l j B$ locus and are monophasic, but some isolates contain a $27 \mathrm{~kb}$ linear plasmid harbouring the $f l j B: z 66$ encoding for a novel flagellin (S. Baker et al., 2007; Frankel et al., 1989). Flagella normally contribute to the virulence through motility and chemotaxis (Macnab, 1999), but can also be implicated during biofilm formation (Crawford et al., 2010a). Flagellin can be detected by TLR-5 present at the cell surface of monocytes, dendritic cells and epithelial cells inducing proinflammatory and adaptive immune responses. In S. Typhi, TviA directly downregulates flagellar expression thereby avoiding its early recognition by the intestinal mucosa (Winter et al., 2008). Flagellar genes are involved in survival within macrophages or during the systemic phase of infection (Bäumler et al., 1994; Chan et al., 2005; Klumpp \& Fuchs, 2007; Libby et al., 2010; Y. Zhao et al., 2002). Nevertheless, the real contribution of the flagellar apparatus is hard to evaluate since expression of the T3SS-1 is co-regulated with the flagella (Eichelberg \& Galán, 2000; Saini et al., 2010). Interestingly, patients harbouring antibodies directed against flagella had uncomplicated typhoid fever, while prevalence of anti-OMP (outer membrane proteins) antibodies was associated with increased ileal perforation rates (Nambiar et al., 2009). 


\subsection{Type 6 secretion systems}

Type 6 secretion systems are newly-discovered structures present in about $25 \%$ of sequenced Gram-negative bacterial genomes (Boyer et al., 2009). In S. enterica subsp. I, T6SS can be identified within SPI-6 (S. Typhi), SPI-19, SPI-20 or SPI-21 (Blondel et al., 2009). T6SS are contractile injection machinery harbouring strong similarities to the tail sheath and spike of bacteriophages (Bönemann et al., 2010). These tubular structures can penetrate eukaryotic as well as prokaryotic membranes in a cell-contact dependant way in order to inject protein effectors. T6SS are often required within phagocytic cells (Ma et al., 2009; Pukatzki et al., 2009), but they can also be implicated in biofilm formation (Aschtgen et al., 2008; EnosBerlage et al., 2005), colonization of the gastrointestinal tract (Blondel et al., 2010), quorum sensing (Weber et al., 2009) as well as in the delivery of toxins to other cells (Hood et al., 2010). Although S. Typhi harbours a pseudogene in a key component of its T6SS, the system is functional and its presence corresponds to an enhanced cytotoxicity toward epithelial cells (M. Wang et al., 2011). T6SS expression is regulated by RcsB, PmrA and Hfq (M. Wang et al., 2011). Its contribution during the interaction with hematopoietic cells should be further studied since a transposon insertion in two genes encoded within SPI-6 showed a competitive disadvantage in humanized mice (Libby et al., 2010).

\begin{tabular}{|c|c|c|c|}
\hline $\begin{array}{c}\text { Surface } \\
\text { structure }\end{array}$ & Role in virulence & $\begin{array}{l}\text { Observed for } \\
\text { S. Typhi }\end{array}$ & $\begin{array}{c}\text { Observed in other } \\
\text { serovars }\end{array}$ \\
\hline Bcf and & Seroconversion & Harris 2006; Hu 2009 & \\
\hline Stb & Intestinal persistence in mice & & Weening 2005 \\
\hline \multirow[t]{2}{*}{ Fim } & $\begin{array}{l}\text { Binds to mannose, adhesion and } \\
\text { invasion of epithelial cells }\end{array}$ & Satta 1993 & Althouse 2003 \\
\hline & Biofilm & & Boddicker 2002 \\
\hline Stg & Adhesion to epithelial cells & Forest 2007 & \\
\hline Sth & Long-term infection of mice & & Lawley 2006 \\
\hline \multirow{2}{*}{ Saf } & Intestinal colonization of swine & & Carnell 2007 \\
\hline & Long-term infection of mice & & Lawley 2006 \\
\hline Sef & Interaction with macrophages & & Edwards 2000 \\
\hline Stc & Intestinal persistence in mice & & Weening 2005 \\
\hline \multirow{2}{*}{ Std } & Binds to $a(1,2)$ fucose & & Chessa 2009 \\
\hline & Intestinal persistence in mice & & Weening 2005 \\
\hline $\begin{array}{l}\text { Tcf and } \\
\text { YaiU }\end{array}$ & Seroconversion & Harris 2006 & \\
\hline \multirow[b]{2}{*}{ Csg } & Seroconversion & Harris 2006 & \\
\hline & Biofilm & & Ledeboer 2006 \\
\hline \multirow{2}{*}{ SiiE } & $\begin{array}{l}\text { Adhesion to apical side of epithelial } \\
\text { cells }\end{array}$ & & Gerlach 2008 \\
\hline & $\begin{array}{l}\text { Colonization of the gastrointestinal } \\
\text { tract }\end{array}$ & & Blondel 2010 \\
\hline BapA & $\begin{array}{l}\text { Interaction with intestinal mucosa, } \\
\text { bacterial autoaggregation and biofilm }\end{array}$ & & Latasa 2005 \\
\hline \multirow{2}{*}{ ShdA } & Seroconversion & Harris 2006 & \\
\hline & Binds to fibronectin & & Kingsley 2002 \\
\hline MisL & $\begin{array}{l}\text { Intestinal colonization, binds to } \\
\text { fibronectin }\end{array}$ & & Dorsey 2005 \\
\hline
\end{tabular}




\begin{tabular}{|c|c|c|c|}
\hline $\begin{array}{c}\text { Surface } \\
\text { structure }\end{array}$ & Role in virulence & $\begin{array}{l}\text { Observed for } \\
\text { S. Typhi }\end{array}$ & $\begin{array}{c}\text { Observed in other } \\
\text { serovars }\end{array}$ \\
\hline \multirow{2}{*}{$\begin{array}{l}\text { Type IVB } \\
\text { pili }\end{array}$} & Binds to CFTR, cellular invasion & Pan 2005; Pier 1998 & \\
\hline & Bacterial self-association & Morris $2003 b$ & Morris $2003 a$ \\
\hline \multirow{2}{*}{ STY0351 } & Seroconversion & Charles 2010 & \\
\hline & Cell adhesion and binds to laminin & Ghosh 2011 & \\
\hline \multirow{4}{*}{ PagC } & Seroconversion & Charles 2010; & \\
\hline & Survival within macrophages & Harris 2006 & Miller 1989 \\
\hline & Serum resistance & & Nishio 2005 \\
\hline & OM vesicle release & & Kitagawa 2010 \\
\hline \multirow{4}{*}{$\begin{array}{c}\mathrm{Vi} \\
\text { Capsule }\end{array}$} & \multirow{2}{*}{ Host immune system evasion } & Kossack 1981; & \\
\hline & & Looney, 1986; & \\
\hline & & Wilson 2011 & \\
\hline & Intramacrophage survival & Hirose 1997 & \\
\hline \multirow{4}{*}{ LPS } & Binds to CFTR & Lyczak 2001 & \\
\hline & Antimicrobial peptides resistance & Baker 1999 & Gunn 2008 \\
\hline & Serum resistance & Hoare 2006 & Bravo 2008 \\
\hline & Intramacrophage survival & Unpublished data & Nagy 2006 \\
\hline T3SS-1 & $\begin{array}{l}\text { Effectors secretion and invasion of } \\
\text { eukaryotic cells }\end{array}$ & $\begin{array}{l}\text { Galán 1991; } \\
\text { Hermant } 1995\end{array}$ & Galán 1989, 1999 \\
\hline T3SS-2 & $\begin{array}{l}\text { Effectors secretion and } \\
\text { intramacrophage survival }\end{array}$ & & $\begin{array}{l}\text { Cirillo 1998; } \\
\text { Hensel 1998 }\end{array}$ \\
\hline \multirow{3}{*}{ Flagella } & Motility and chemotaxis & Liu 1988 & Macnab 1999 \\
\hline & Intramacrophage survival & Unpublished data & Bäumler 1994 \\
\hline & Biofilm formation & & Crawford 2010a \\
\hline T6SS & $\begin{array}{l}\text { Colonization of the gastrointestinal } \\
\text { tract }\end{array}$ & & Blondel 2010 \\
\hline
\end{tabular}

Table 1. S. Typhi surface structures considered in this review and their roles in virulence.

\section{Future perspectives}

The multidrug-resistance observed for $S$. Typhi strains is of great concern since the total number of cases has increased during the last decade (Crump et al., 2004; Pang et al., 1998). There are two crucial lines of defence that should be improved in order to win the combat against typhoid fever : prevention and treatment. The best vaccine would be safe, given in a single dose, offering an efficient and long lasting immunity and remain stable at room temperature. Next generation vaccines have been recently tested in human trials (reviewed in Lindow et al., 2011). The expression of surface structures is tightly coordinated to avoid recognition by the immune system. Nevertheless, we have some clues regarding the structures recognized during typhoid fever (Charles et al., 2010; Harris et al., 2006; Hu et al., 2009). Since antibodies promote killing of $S$. Typhi (Lindow et al., 2011), a good approach to improve the efficiency of vaccines might be to create an avirulent strain expressing its immunogenic structures on inducible promoters inside antigen presenting cells (S. Wang et al., 2011).

Another strategy in the fight against $S$. Typhi should be the identification and treatment of the 1-5\% infected individuals who become asymptomatic carriers (Crawford et al., 2010b; Parry et al., 2002). This task is complicated as antibiotherapy is often unsuccessful to remove 
biofilms found in the gallbladder, especially on gallstones, and surgical removal of the gallbladder is usually required but expensive (Crawford et al., 2010b; Prouty et al., 2002) Hence, efforts should be taken to understand the specific structures required for biofilm formation by $S$. Typhi in order to develop therapies to eliminate typhoid carriage.

Novel strategies are being developed to target surface structures implicated in bacterial pathogenesis as potential treatments (reviewed in Lynch \& Wiener-Kronish, 2008). For example, pilicides are small compounds preventing interactions between the OM usher and chaperone-subunits complexes of type 1 pili, hence interfering with fimbrial biogenesis (Pinkner et al., 2006). Since most surface structures of Salmonella are expressed by the CUP, targeting the fimbrial ushers might be a useful method to eliminate colonisation and avoid the resulting antimicrobial resistance. Moreover, curlicides are able to interfere with CsgA polymerization as well as type 1 fimbrial biogenesis resulting in the blocking of biofilm accumulation (Cegelski et al., 2009). Similarly, small-molecule inhibitors and inactivating antibodies can target binding or translocation of effectors by T3SS (Hudson et al., 2007; Neely et al., 2005; Nordfelth et al., 2005; Swietnicki et al., 2011). Targeting the capsule or LPS biosynthetic pathways might be a good approach to fight against $S$. Typhi since there is no corresponding enzyme in its human host (Cipolla et al., 2010; Goller \& Seed, 2010).

Finally, understanding the role and function of $S$. Typhi surface proteins is primordial as these molecules are the first ones to directly interact with host components or cells, leading to a possibility for the development of new strategies to fight typhoid (see Table 1).

\section{Acknowledgments}

This work was supported by the Canadian Natural Sciences and Engineering Research Council (NSERC) grant number 251114-06. C.G.F. was supported by scholarships from NSERC. We are grateful to Dr. George Szatmari for editing of the manuscript.

\section{References}

Althouse, C., Patterson, S., Fedorka-Cray, P. \& Isaacson, R. E. (2003). Type 1 fimbriae of Salmonella enterica serovar Typhimurium bind to enterocytes and contribute to colonization of swine in vivo. Infection and Immunity, Vol. 71, No. 11, pp. 6446-6452, ISSN 0019-9567

Altier, C. (2005). Genetic and environmental control of Salmonella invasion. Journal of Microbiology, Vol. 43 Spec No, pp. 85-92, ISSN 1225-8873

Altschul, S. F., Gish, W., Miller, W., Myers, E. W. \& Lipman, D. J. (1990). Basic local alignment search tool. Journal of Molecular Biology, Vol. 215, No. 3, pp. 403-410, ISSN 0022-2836

Arricau, N., Hermant, D., Waxin, H., Ecobichon, C., Duffey, P. S. \& Popoff, M. Y. (1998). The RcsB-RcsC regulatory system of Salmonella typhi differentially modulates the expression of invasion proteins, flagellin and $\mathrm{Vi}$ antigen in response to osmolarity. Molecular Microbiology, Vol. 29, No. 3, pp. 835-850, ISSN 0950-382X

Aschtgen, M. S., Bernard, C. S., De Bentzmann, S., Lloubès, R. \& Cascales, E. (2008). SciN is an outer membrane lipoprotein required for type VI secretion in enteroaggregative Escherichia coli. Journal of Bacteriology, Vol. 190, No. 22, pp. 7523-7531, ISSN 1098-5530 
Bajaj, V., Lucas, R. L., Hwang, C. \& Lee, C. A. (1996). Co-ordinate regulation of Salmonella typhimurium invasion genes by environmental and regulatory factors is mediated by control of hilA expression. Molecular Microbiology, Vol. 22, No. 4, pp. 703-714, ISSN 0950-382X

Baker, S., Hardy, J., Sanderson, K. E., Quail, M., Goodhead, I., Kingsley, R. A., Parkhill, J., Stocker, B. \& Dougan, G. (2007). A novel linear plasmid mediates flagellar variation in Salmonella Typhi. PLoS Pathogens, Vol. 3, No. 5, p. e59, ISSN 1553-7374

Baker, S. J., Gunn, J. S. \& Morona, R. (1999). The Salmonella typhi melittin resistance gene pqaB affects intracellular growth in PMA-differentiated U937 cells, polymyxin B resistance and lipopolysaccharide. Microbiology, Vol. 145, No. 2, pp. 367-378, ISSN 1350-0872

Bäumler, A. J., Kusters, J. G., Stojiljkovic, I. \& Heffron, F. (1994). Salmonella typhimurium loci involved in survival within macrophages. Infection and Immunity, Vol. 62, No. 5, pp. 1623-1630, ISSN 0019-9567

Bishop, A., House, D., Perkins, T., Baker, S., Kingsley, R. A. \& Dougan, G. (2008). Interaction of Salmonella enterica serovar Typhi with cultured epithelial cells: roles of surface structures in adhesion and invasion. Microbiology, Vol. 154, No. 7, pp. 1914-1926, ISSN 1350-0872

Bittner, M., Saldías, S., Estévez, C., Zaldívar, M., Marolda, C. L., Valvano, M. A. \& Contreras, I. (2002). O-antigen expression in Salmonella enterica serovar Typhi is regulated by nitrogen availability through RpoN-mediated transcriptional control of the $r f a H$ gene. Microbiology, Vol. 148, No. 12, pp. 3789-3799, ISSN 1350-0872

Blondel, C. J., Jiménez, J. C., Contreras, I. \& Santiviago, C. A. (2009). Comparative genomic analysis uncovers 3 novel loci encoding type six secretion systems differentially distributed in Salmonella serotypes. BMC Genomics, Vol. 10, p. 354, ISSN 1471-2164

Blondel, C. J., Yang, H. J., Castro, B., Chiang, S., Toro, C. S., Zaldívar, M., Contreras, I., Andrews-Polymenis, H. L. \& Santiviago, C. A. (2010). Contribution of the type VI secretion system encoded in SPI-19 to chicken colonization by Salmonella enterica serotypes Gallinarum and Enteritidis. PLoS One, Vol. 5, No. 7, p. e11724, ISSN 1932-6203

Boddicker, J. D., Ledeboer, N. A., Jagnow, J., Jones, B. D. \& Clegg, S. (2002). Differential binding to and biofilm formation on, HEp-2 cells by Salmonella enterica serovar Typhimurium is dependent upon allelic variation in the fim $\mathrm{H}$ gene of the fim gene cluster. Molecular Microbiology, Vol. 45, No. 5, pp. 1255-1265, ISSN 0950-382X

Bönemann, G., Pietrosiuk, A. \& Mogk, A. (2010). Tubules and donuts: a type VI secretion story. Molecular Microbiology, Vol. 76, No. 4, pp. 815-821, ISSN 1365-2958

Boyer, F., Fichant, G., Berthod, J., Vandenbrouck, Y. \& Attree, I. (2009). Dissecting the bacterial type VI secretion system by a genome wide in silico analysis: what can be learned from available microbial genomic resources? BMC Genomics, Vol. 10, p. 104, ISSN 1471-2164

Bravo, D., Silva, C., Carter, J. A., Hoare, A., Alvarez, S. A., Blondel, C. J., Zaldivar, M., Valvano, M. A. \& Contreras, I. (2008). Growth-phase regulation of lipopolysaccharide Oantigen chain length influences serum resistance in serovars of Salmonella. Journal of Medical Microbiology, Vol. 57, No. 8, pp. 938-946, ISSN 0022-2615

Bravo, D., Hoare, A., Silipo, A., Valenzuela, C., Salinas, C., Alvarez, S. A., Molinaro, A., Valvano, M. A. \& Contreras, I. (2011). Different sugar residues of the 
lipopolysaccharide outer core are required for early interactions of Salmonella enterica serovars Typhi and Typhimurium with epithelial cells. Microbial Pathogenesis, Vol. 50, No. 2, pp. 70-80, ISSN 1096-1208

Brumell, J. H., Rosenberger, C. M., Gotto, G. T., Marcus, S. L. \& Finlay, B. B. (2001). SifA permits survival and replication of Salmonella typhimurium in murine macrophages. Cellular Microbiology, Vol. 3, No. 2, pp. 75-84, ISSN 1462-5814

Carnell, S. C., Bowen, A., Morgan, E., Maskell, D. J., Wallis, T. S. \& Stevens, M. P. (2007). Role in virulence and protective efficacy in pigs of Salmonella enterica serovar Typhimurium secreted components identified by signature-tagged mutagenesis. Microbiology, Vol. 153, No. 6, pp. 1940-1952, ISSN 1350-0872

Cegelski, L., Pinkner, J. S., Hammer, N. D. \& other authors. (2009). Small-molecule inhibitors target Escherichia coli amyloid biogenesis and biofilm formation. Nature Chemical Biology, Vol. 5, No. 12, pp. 913-919, ISSN 1552-4469

Chan, K., Kim, C. C. \& Falkow, S. (2005). Microarray-based detection of Salmonella enterica serovar Typhimurium transposon mutants that cannot survive in macrophages and mice. Infection and Immunity, Vol. 73, No. 9, pp. 5438-5449, ISSN 0019-9567

Charles, R. C., Harris, J. B., Chase, M. R. \& other authors. (2009). Comparative proteomic analysis of the PhoP regulon in Salmonella enterica serovar Typhi versus Typhimurium. PLoS One, Vol. 4, No. 9, p. e6994, ISSN 1932-6203

Charles, R. C., Sheikh, A., Krastins, B. \& other authors. (2010). Characterization of antiSalmonella enterica serotype Typhi antibody responses in bacteremic Bangladeshi patients by an immunoaffinity proteomics-based technology. Clinical and Vaccine Immunology, Vol. 17, No. 8, pp. 1188-1195, ISSN 1556-679X

Chessa, D., Winter, M. G., Nuccio, S. P., Tükel, C. \& Bäumler, A. J. (2008). RosE represses Std fimbrial expression in Salmonella enterica serotype Typhimurium. Molecular Microbiology, Vol. 68, No. 3, pp. 573-587, ISSN 1365-2958

Chessa, D., Winter, M. G., Jakomin, M. \& Bäumler, A. J. (2009). Salmonella enterica serotype Typhimurium Std fimbriae bind terminal alpha(1,2)fucose residues in the cecal mucosa. Molecular Microbiology, Vol. 71, No. 4, pp. 864-875, ISSN 1365-2958

Chevance, F. F. \& Hughes, K. T. (2008). Coordinating assembly of a bacterial macromolecular machine. Nature Reviews Microbiology, Vol. 6, No. 6, pp. 455-465, ISSN 1740-1534

China, B. \& Goffaux, F. (1999). Secretion of virulence factors by Escherichia coli. Veterinary Research, Vol. 30, No. 2-3, pp. 181-202, ISSN 0928-4249

Cipolla, L., Gabrielli, L., Bini, D., Russo, L. \& Shaikh, N. (2010). Kdo: a critical monosaccharide for bacteria viability. Natural Product Reports, Vol. 27, No. 11, pp. 1618-1629, ISSN 1460-4752

Cirillo, D. M., Valdivia, R. H., Monack, D. M. \& Falkow, S. (1998). Macrophage-dependent induction of the Salmonella pathogenicity island 2 type III secretion system and its role in intracellular survival. Molecular Microbiology, Vol. 30, No. 1, pp. 175-188, ISSN 0950-382X

Craig, L. \& Li, J. (2008). Type IV pili: paradoxes in form and function. Current Opinion in Structural Biology, Vol. 18, No. 2, pp. 267-277, ISSN 0959-440X

Crawford, R. W., Reeve, K. E. \& Gunn, J. S. (2010a). Flagellated but not hyperfimbriated Salmonella enterica serovar Typhimurium attaches to and forms biofilms on cholesterol-coated surfaces. Journal of Bacteriology, Vol. 192, No. 12, pp. 2981-2990, ISSN 1098-5530 
Crawford, R. W., Rosales-Reyes, R., Ramírez-Aguilar, M. e. L., Chapa-Azuela, O., AlpucheAranda, C. \& Gunn, J. S. (2010b). Gallstones play a significant role in Salmonella spp. gallbladder colonization and carriage. Proceedings of the National Academy of Sciences of the United States of America, Vol. 107, No. 9, pp. 4353-4358, ISSN 1091-6490

Crump, J. A., Luby, S. P. \& Mintz, E. D. (2004). The global burden of typhoid fever. Bulletin of the World Health Organization, Vol. 82, No. 5, pp. 346-353, ISSN 0042-9686

Daigle, F., Graham, J. E. \& Curtiss III, R. (2001). Identification of Salmonella typhi genes expressed within macrophages by selective capture of transcribed sequences (SCOTS). Molecular Microbiology, Vol. 41, No. 5, pp. 1211-1222, ISSN 0950-382X

Dorsey, C. W., Laarakker, M. C., Humphries, A. D., Weening, E. H. \& Bäumler, A. J. (2005). Salmonella enterica serotype Typhimurium MisL is an intestinal colonization factor that binds fibronectin. Molecular Microbiology, Vol. 57, No. 1, pp. 196-211, ISSN 0950-382X

Duguid, J. P., Anderson, E. S. \& Campbell, I. (1966). Fimbriae and adhesive properties in Salmonellae. Journal of Pathology and Bacteriology, Vol. 92, No. 1, pp. 107-138, ISSN 0368-3494

Edwards, R. A., Schifferli, D. M. \& Maloy, S. R. (2000). A role for Salmonella fimbriae in intraperitoneal infections. Proceedings of the National Academy of Sciences of the United States of America, Vol. 97, No. 3, pp. 1258-1262, ISSN 0027-8424

Eichelberg, K. \& Galán, J. E. (2000). The flagellar sigma factor FliA (sigma(28)) regulates the expression of Salmonella genes associated with the centisome 63 type III secretion system. Infection and Immunity, Vol. 68, No. 5, pp. 2735-2743, ISSN 0019-9567

Enos-Berlage, J. L., Guvener, Z. T., Keenan, C. E. \& McCarter, L. L. (2005). Genetic determinants of biofilm development of opaque and translucent Vibrio parahaemolyticus. Molecular Microbiology, Vol. 55, No. 4, pp. 1160-1182, ISSN 0950-382X

Faucher, S. P., Porwollik, S., Dozois, C. M., McClelland, M. \& Daigle, F. (2006). Transcriptome of Salmonella enterica serovar Typhi within macrophages revealed through the selective capture of transcribed sequences. Proceedings of the National Academy of Sciences of the United States of America, Vol. 103, No. 6, pp. 1906-1911, ISSN 0027-8424

Felix, A. \& Pitt, R. M. (1934). A new antigen of B. typhosus. The Lancet, Vol. 224, No. 5787, pp. 186-191, ISSN 0140-6736

Forest, C., Faucher, S. P., Poirier, K., Houle, S., Dozois, C. M. \& Daigle, F. (2007). Contribution of the stg fimbrial operon of Salmonella enterica serovar Typhi during interaction with human cells. Infection and Immunity, Vol. 75, No. 11, pp. 5264-5271, ISSN 0019-9567

Forest, C. G., Ferraro, E., Sabbagh, S. C. \& Daigle, F. (2010). Intracellular survival of Salmonella enterica serovar Typhi in human macrophages is independent of Salmonella pathogenicity island (SPI)-2. Microbiology, Vol. 156, No. 12, pp. 36893698, ISSN 1465-2080

Frankel, G., Newton, S. M., Schoolnik, G. K. \& Stocker, B. A. (1989). Intragenic recombination in a flagellin gene: characterization of the H1-j gene of Salmonella typhi. EMBO Journal, Vol. 8, No. 10, pp. 3149-3152, ISSN 0261-4189

Galán, J. E. \& Curtiss III, R. (1989). Cloning and molecular characterization of genes whose products allow Salmonella typhimurium to penetrate tissue culture cells. Proceedings 
of the National Academy of Sciences of the United States of America, Vol. 86, No. 16, pp. 6383-6387, ISSN 0027-8424

Galán, J. E. \& Curtiss III, R. (1990). Expression of Salmonella typhimurium genes required for invasion is regulated by changes in DNA supercoiling. Infection and Immunity, Vol. 58, No. 6, pp. 1879-1885, ISSN 0019-9567

Galán, J. E. \& Curtiss III, R. (1991). Distribution of the invA, -B, -C, and -D genes of Salmonella typhimurium among other Salmonella serovars: invA mutants of Salmonella typhi are deficient for entry into mammalian cells. Infection and Immunity, Vol. 59, No. 9, pp. 2901-2908, ISSN 0019-9567

Galán, J. E. (1999). Interaction of Salmonella with host cells through the centisome 63 type III secretion system. Current Opinion in Microbiology, Vol. 2, No. 1, pp. 46-50, ISSN 1369-5274

Gerlach, R. G., Jäckel, D., Stecher, B., Wagner, C., Lupas, A., Hardt, W. D. \& Hensel, M. (2007). Salmonella Pathogenicity Island 4 encodes a giant non-fimbrial adhesin and the cognate type 1 secretion system. Cellular Microbiology, Vol. 9, No. 7, pp. 18341850, ISSN 1462-5814

Gerlach, R. G., Cláudio, N., Rohde, M., Jäckel, D., Wagner, C. \& Hensel, M. (2008). Cooperation of Salmonella pathogenicity islands 1 and 4 is required to breach epithelial barriers. Cellular Microbiology, Vol. 10, No. 11, pp. 2364-2376, ISSN $1462-5822$

Ghosh, S., Chakraborty, K., Nagaraja, T., Basak, S., Koley, H., Dutta, S., Mitra, U. \& Das, S. (2011). An adhesion protein of Salmonella enterica serovar Typhi is required for pathogenesis and potential target for vaccine development. Proceedings of the National Academy of Sciences of the United States of America, Vol. 108, No. 8, pp. 33483353, ISSN 1091-6490

Goller, C. C. \& Seed, P. C. (2010). High-throughput identification of chemical inhibitors of $E$. coli Group 2 capsule biogenesis as anti-virulence agents. PLoS One, Vol. 5, No. 7, p. e11642, ISSN 1932-6203

Grosskinsky, U., Schütz, M., Fritz, M., Schmid, Y., Lamparter, M. C., Szczesny, P., Lupas, A. N., Autenrieth, I. B. \& Linke, D. (2007). A conserved glycine residue of trimeric autotransporter domains plays a key role in Yersinia adhesin A autotransport. Journal of Bacteriology, Vol. 189, No. 24, pp. 9011-9019, ISSN 1098-5530

Gunn, J. S. (2008). The Salmonella PmrAB regulon: lipopolysaccharide modifications, antimicrobial peptide resistance and more. Trends in Microbiology, Vol. 16, No. 6, pp. 284-290, ISSN 0966-842X

Hammar, M., Bian, Z. \& Normark, S. (1996). Nucleator-dependent intercellular assembly of adhesive curli organelles in Escherichia coli. Proceedings of the National Academy of Sciences of the United States of America, Vol. 93, No. 13, pp. 6562-6566, ISSN 0027-8424

Haraga, A., Ohlson, M. B. \& Miller, S. I. (2008). Salmonellae interplay with host cells. Nature Reviews Microbiology, Vol. 6, No. 1, pp. 53-66, ISSN 1740-1534

Harris, J. B., Baresch-Bernal, A., Rollins, S. M. \& other authors. (2006). Identification of in vivoinduced bacterial protein antigens during human infection with Salmonella enterica serovar Typhi. Infection and Immunity, Vol. 74, No. 9, pp. 5161-5168, ISSN 0019-9567

Harshey, R. M. (2011). New insights into the role and formation of flagella in Salmonella, In: Salmonella: from genome to function, S. Porwollik (Ed.), pp. 163-186, Caister Academic Press, ISBN 978-1-904455-73-8, Norfolk 
Hashimoto, Y., Khan, A. Q. \& Ezaki, T. (1996). Positive autoregulation of vipR expression in ViaB region-encoded Vi antigen of Salmonella typhi. Journal of Bacteriology, Vol. 178, No. 5, pp. 1430-1436, ISSN 0021-9193

Hensel, M., Shea, J. E., Waterman, S. R. \& other authors. (1998). Genes encoding putative effector proteins of the type III secretion system of Salmonella pathogenicity island 2 are required for bacterial virulence and proliferation in macrophages. Molecular Microbiology, Vol. 30, No. 1, pp. 163-174, ISSN 0950-382X

Hermant, D., Ménard, R., Arricau, N., Parsot, C. \& Popoff, M. Y. (1995). Functional conservation of the Salmonella and Shigella effectors of entry into epithelial cells. Molecular Microbiology, Vol. 17, No. 4, pp. 781-789, ISSN 0950-382X

Heyns, K., Kiessling, G., Lindenberg, W., Paulsen, H. \& Webster, M. E. (1959). DGalaktosaminuornsaure (2-amino-2-desoxy-D-galakturonsaure) als Baustein des Vi-Antigens. Chemische Berichte, Vol. 92, No. 10, pp. 2435-2437, ISSN 1099-0682

Hirose, K., Ezaki, T., Miyake, M., Li, T., Khan, A. Q., Kawamura, Y., Yokoyama, H. \& Takami, T. (1997). Survival of Vi-capsulated and Vi-deleted Salmonella typhi strains in cultured macrophage expressing different levels of CD14 antigen. FEMS Microbiology Letters, Vol. 147, No. 2, pp. 259-265, ISSN 0378-1097

Hoare, A., Bittner, M., Carter, J., Alvarez, S., Zaldívar, M., Bravo, D., Valvano, M. A. \& Contreras, I. (2006). The outer core lipopolysaccharide of Salmonella enterica serovar Typhi is required for bacterial entry into epithelial cells. Infection and Immunity, Vol. 74, No. 3, pp. 1555-1564, ISSN 0019-9567

Holt, K. E., Thomson, N. R., Wain, J. \& other authors. (2009). Pseudogene accumulation in the evolutionary histories of Salmonella enterica serovars Paratyphi A and Typhi. BMC Genomics, Vol. 10, p. 36, ISSN 1471-2164

Hölzer, S. U., Schlumberger, M. C., Jäckel, D. \& Hensel, M. (2009). Effect of the O-antigen length of lipopolysaccharide on the functions of Type III secretion systems in Salmonella enterica. Infection and Immunity, Vol. 77, No. 12, pp. 5458-5470, ISSN 1098-5522

Hood, R. D., Singh, P., Hsu, F. \& other authors. (2010). A type VI secretion system of Pseudomonas aeruginosa targets a toxin to bacteria. Cell Host Microbe, Vol. 7, No. 1, pp. 25-37, ISSN 1934-6069

Hu, Y., Cong, Y., Li, S., Rao, X., Wang, G. \& Hu, F. (2009). Identification of in vivo induced protein antigens of Salmonella enterica serovar Typhi during human infection. Science in China Series C, Life Sciences, Vol. 52, No. 10, pp. 942-948, ISSN 1862-2798

Hudson, D. L., Layton, A. N., Field, T. R., Bowen, A. J., Wolf-Watz, H., Elofsson, M., Stevens, M. P. \& Galyov, E. E. (2007). Inhibition of type III secretion in Salmonella enterica serovar Typhimurium by small-molecule inhibitors. Antimicrobial Agents and Chemotherapy, Vol. 51, No. 7, pp. 2631-2635, ISSN 0066-4804

Humphries, A. D., Raffatellu, M., Winter, S. \& other authors. (2003). The use of flow cytometry to detect expression of subunits encoded by 11 Salmonella enterica serotype Typhimurium fimbrial operons. Molecular Microbiology, Vol. 48, No. 5, pp. 1357-1376, ISSN 0950-382X

Jacob-Dubuisson, F., Striker, R. \& Hultgren, S. J. (1994). Chaperone-assisted self-assembly of pili independent of cellular energy. Journal of Biological Chemistry, Vol. 269, No. 17, pp. 12447-12455, ISSN 0021-9258 
Janis, C., Grant, A. J., McKinley, T. J., Morgan, F. J., John, V. F., Houghton, J., Kingsley, R. A., Dougan, G. \& Mastroeni, P. (2011). In vivo regulation of the Vi antigen in Salmonella and induction of immune responses with an in vivo-inducible promoter. Infection and Immunity, Vol. 79, No. 6, pp. 2481-2488, ISSN 1098-5522

Jonas, K., Tomenius, H., Kader, A., Normark, S., Römling, U., Belova, L. M. \& Melefors, O. (2007). Roles of curli, cellulose and BapA in Salmonella biofilm morphology studied by atomic force microscopy. BMC Microbiology, Vol. 7, p. 70, ISSN 1471-2180

Jones, B. D. \& Falkow, S. (1994). Identification and characterization of a Salmonella typhimurium oxygen-regulated gene required for bacterial internalization. Infection and Immunity, Vol. 62, No. 9, pp. 3745-3752, ISSN 0019-9567

Karlinsey, J. E., Tanaka, S., Bettenworth, V., Yamaguchi, S., Boos, W., Aizawa, S. I. \& Hughes, K. T. (2000). Completion of the hook-basal body complex of the Salmonella typhimurium flagellum is coupled to FlgM secretion and fliC transcription. Molecular Microbiology, Vol. 37, No. 5, pp. 1220-1231, ISSN 0950-382X

Kidgell, C., Reichard, U., Wain, J., Linz, B., Torpdahl, M., Dougan, G. \& Achtman, M. (2002). Salmonella typhi, the causative agent of typhoid fever, is approximately 50,000 years old. Infection, genetic and evolution, Vol. 2, No. 1, pp. 39-45, ISSN 1567-1348

Kimbrough, T. \& Miller, S. (2000). Contribution of Salmonella typhimurium type III secretion components to needle complex formation. Proceedings of the National Academy of Sciences of the United States of America, Vol. 97, No. 20, pp. 11008-11013, ISSN 0027-8424

Kingsley, R. A., Santos, R. L., Keestra, A. M., Adams, L. G. \& Bäumler, A. J. (2002). Salmonella enterica serotype Typhimurium ShdA is an outer membrane fibronectin-binding protein that is expressed in the intestine. Molecular Microbiology, Vol. 43, No. 4, pp. 895-905, ISSN 0950-382X

Kitagawa, R., Takaya, A., Ohya, M., Mizunoe, Y., Takade, A., Yoshida, S., Isogai, E. \& Yamamoto, T. (2010). Biogenesis of Salmonella enterica serovar Typhimurium membrane vesicles provoked by induction of PagC. Journal of Bacteriology, Vol. 192, No. 21, pp. 5645-5656, ISSN 1098-5530

Klumpp, J. \& Fuchs, T. M. (2007). Identification of novel genes in genomic islands that contribute to Salmonella typhimurium replication in macrophages. Microbiology, Vol. 153, No. 4, pp. 1207-1220, ISSN 1350-0872

Korea, C. G., Ghigo, J. M. \& Beloin, C. (2011). The sweet connection: Solving the riddle of multiple sugar-binding fimbrial adhesins in Escherichia coli: Multiple E. coli fimbriae form a versatile arsenal of sugar-binding lectins potentially involved in surfacecolonisation and tissue tropism. Bioessays, Vol. 33, No. 4, pp. 300-311, ISSN 1521-1878

Kossack, R. E., Guerrant, R. L., Densen, P., Schadelin, J. \& Mandell, G. L. (1981). Diminished neutrophil oxidative metabolism after phagocytosis of virulent Salmonella typhi. Infection and Immunity, Vol. 31, No. 2, pp. 674-678, ISSN 0019-9567

Krachler, A. M., Ham, H. \& Orth, K. (2011). Outer membrane adhesion factor multivalent adhesion molecule 7 initiates host cell binding during infection by Gram-negative pathogens. Proceedings of the National Academy of Sciences of the United States of America, Vol. 108, No. 28, pp. 11614-11619, ISSN 1091-6490

Kubori, T., Matsushima, Y., Nakamura, D., Uralil, J., Lara-Tejero, M., Sukhan, A., Galan, J. E. \& Aizawa, S. I. (1998). Supramolecular structure of the Salmonella typhimurium type III protein secretion system. Science, Vol. 280, No. 5363, pp. 602-605, ISSN 0036-8075 
Kutsukake, K., Ohya, Y. \& Iino, T. (1990). Transcriptional analysis of the flagellar regulon of Salmonella typhimurium. Journal of Bacteriology, Vol. 172, No. 2, pp. 741-747, ISSN 0021-9193

Latasa, C., Roux, A., Toledo-Arana, A., Ghigo, J. M., Gamazo, C., Penadés, J. R. \& Lasa, I. (2005). BapA, a large secreted protein required for biofilm formation and host colonization of Salmonella enterica serovar Enteritidis. Molecular Microbiology, Vol. 58, No. 5, pp. 1322-1339, ISSN 0950-382X

Lawley, T. D., Chan, K., Thompson, L. J., Kim, C. C., Govoni, G. R. \& Monack, D. M. (2006). Genome-wide screen for Salmonella genes required for long-term systemic infection of the mouse. PLoS Pathogens, Vol. 2, No. 2, p. e11, ISSN 1553-7374

Ledeboer, N. A., Frye, J. G., McClelland, M. \& Jones, B. D. (2006). Salmonella enterica serovar Typhimurium requires the Lpf, Pef, and Tafi fimbriae for biofilm formation on HEp-2 tissue culture cells and chicken intestinal epithelium. Infection and Immunity, Vol. 74, No. 6, pp. 3156-3169, ISSN 0019-9567

Lederberg, J. \& Iino, T. (1956). Phase Variation in Salmonella. Genetics, Vol. 41, No. 5, pp. $743-$ 757, ISSN 0016-6731

Libby, S. J., Brehm, M. A., Greiner, D. L. \& other authors. (2010). Humanized nonobese diabetic-scid IL2rgammanull mice are susceptible to lethal Salmonella Typhi infection. Proceedings of the National Academy of Sciences of the United States of America, Vol. 107, No. 35, pp. 15589-15594, ISSN 1091-6490

Lindow, J. C., Fimlaid, K. A., Bunn, J. Y. \& Kirkpatrick, B. D. (2011). Antibodies in Action: Role of Human Opsonins in Killing Salmonella enterica Serovar Typhi. Infection and Immunity, Vol. 79, No. 8, pp. 3188-3194, ISSN 1098-5522

Liu, S. L., Ezaki, T., Miura, H., Matsui, K. \& Yabuuchi, E. (1988). Intact motility as a Salmonella typhi invasion-related factor. Infection and Immunity, Vol. 56, No. 8, pp. 1967-1973, ISSN 0019-9567

Looney, R. J. \& Steigbigel, R. T. (1986). Role of the Vi antigen of Salmonella typhi in resistance to host defense in vitro. Journal of Laboratory and Clinical Medicine, Vol. 108, No. 5, pp. 506-516, ISSN 0022-2143

Lyczak, J. B., Zaidi, T. S., Grout, M., Bittner, M., Contreras, I. \& Pier, G. B. (2001). Epithelial cell contact-induced alterations in Salmonella enterica serovar Typhi lipopolysaccharide are critical for bacterial internalization. Cellular Microbiology, Vol. 3, No. 11, pp. 763-772, ISSN 1462-5814

Lyczak, J. B. \& Pier, G. B. (2002). Salmonella enterica serovar Typhi modulates cell surface expression of its receptor, the cystic fibrosis transmembrane conductance regulator, on the intestinal epithelium. Infection and Immunity, Vol. 70, No. 11, pp. 6416-6423, ISSN 0019-9567

Lynch, S. V. \& Wiener-Kronish, J. P. (2008). Novel strategies to combat bacterial virulence. Current Opinion in Critical Care, Vol. 14, No. 5, pp. 593-599, ISSN 1531-7072

Ma, A. T., McAuley, S., Pukatzki, S. \& Mekalanos, J. J. (2009). Translocation of a Vibrio cholerae type VI secretion effector requires bacterial endocytosis by host cells. Cell Host Microbe, Vol. 5, No. 3, pp. 234-243, ISSN 1934-6069

Macnab, R. M. (1999). The bacterial flagellum: reversible rotary propellor and type III export apparatus. Journal of Bacteriology, Vol. 181, No. 23, pp. 7149-7153, ISSN 0021-9193

Main-Hester, K. L., Colpitts, K. M., Thomas, G. A., Fang, F. C. \& Libby, S. J. (2008). Coordinate regulation of Salmonella pathogenicity island 1 (SPI1) and SPI4 in 
Salmonella enterica serovar Typhimurium. Infection and Immunity, Vol. 76, No. 3, pp. 1024-1035, ISSN 1098-5522

Mattick, J. S. (2002). Type IV pili and twitching motility. Annual Review of Microbiology, Vol. 56, pp. 289-314, ISSN 0066-4227

Miller, S. I., Kukral, A. M. \& Mekalanos, J. J. (1989). A two-component regulatory system (phoP phoQ) controls Salmonella typhimurium virulence. Proceedings of the National Academy of Sciences of the United States of America, Vol. 86, No. 13, pp. 5054-5058, ISSN 0027-8424

Minamino, T. \& Namba, K. (2008). Distinct roles of the FliI ATPase and proton motive force in bacterial flagellar protein export. Nature, Vol. 451, No. 7177, pp. 485-488, ISSN 1476-4687

Miras, I., Hermant, D., Arricau, N. \& Popoff, M. Y. (1995). Nucleotide sequence of iagA and iagB genes involved in invasion of HeLa cells by Salmonella enterica subsp. enterica ser. Typhi. Research in Microbiology, Vol. 146, No. 1, pp. 17-20, ISSN 0923-2508

Miyake, M., Zhao, L., Ezaki, T. \& other authors. (1998). Vi-deficient and nonfimbriated mutants of Salmonella typhi agglutinate human blood type antigens and are hyperinvasive. FEMS Microbiology Letters, Vol. 161, No. 1, pp. 75-82, ISSN 0378-1097

Morgan, E., Campbell, J. D., Rowe, S. C., Bispham, J., Stevens, M. P., Bowen, A. J., Barrow, P. A., Maskell, D. J. \& Wallis, T. S. (2004). Identification of host-specific colonization factors of Salmonella enterica serovar Typhimurium. Molecular Microbiology, Vol. 54, No. 4, pp. 994-1010, ISSN 0950-382X

Morris, C., Tam, C. K., Wallis, T. S., Jones, P. W. \& Hackett, J. (2003a). Salmonella enterica serovar Dublin strains which are Vi antigen-positive use type IVB pili for bacterial self-association and human intestinal cell entry. Microbial Pathogenesis, Vol. 35, No. 6, pp. 279-284, ISSN 0882-4010

Morris, C., Yip, C. M., Tsui, I. S., Wong, D. K. \& Hackett, J. (2003b). The shufflon of Salmonella enterica serovar Typhi regulates type IVB pilus-mediated bacterial selfassociation. Infection and Immunity, Vol. 71, No. 3, pp. 1141-1146, ISSN 0019-9567

Nagy, G., Danino, V., Dobrindt, U., Pallen, M., Chaudhuri, R., Emödy, L., Hinton, J. C. \& Hacker, J. (2006). Down-regulation of key virulence factors makes the Salmonella enterica serovar Typhimurium $\mathrm{rfaH}$ mutant a promising live-attenuated vaccine candidate. Infection and Immunity, Vol. 74, No. 10, pp. 5914-5925, ISSN 0019-9567

Nambiar, M., Harish, B. N., Mangilal, V., Pai, D. \& Parija, S. C. (2009). Immunoblot analysis of sera in uncomplicated typhoid fever \& with typhoid ileal perforation. Indian Journal of Medical Research, Vol. 129, No. 4, pp. 432-437, ISSN 0971-5916

Neely, A. N., Holder, I. A., Wiener-Kronish, J. P. \& Sawa, T. (2005). Passive anti-PcrV treatment protects burned mice against Pseudomonas aeruginosa challenge. Burns, Vol. 31, No. 2, pp. 153-158, ISSN 0305-4179

Nishimura, K., Tajima, N., Yoon, Y. H., Park, S. Y. \& Tame, J. R. (2010). Autotransporter passenger proteins: virulence factors with common structural themes. Journal of Molecular Medicine, Vol. 88, No. 5, pp. 451-458, ISSN 1432-1440

Nishio, M., Okada, N., Miki, T., Haneda, T. \& Danbara, H. (2005). Identification of the outer-membrane protein $\mathrm{PagC}$ required for the serum resistance phenotype in Salmonella enterica serovar Choleraesuis. Microbiology, Vol. 151, No. 3, pp. 863-873, ISSN 1350-0872 
Nishiyama, M., Ishikawa, T., Rechsteiner, H. \& Glockshuber, R. (2008). Reconstitution of pilus assembly reveals a bacterial outer membrane catalyst. Science, Vol. 320, No. 5874, pp. 376-379, ISSN 1095-9203

Nordfelth, R., Kauppi, A. M., Norberg, H. A., Wolf-Watz, H. \& Elofsson, M. (2005). Smallmolecule inhibitors specifically targeting type III secretion. Infection and Immunity, Vol. 73, No. 5, pp. 3104-3114, ISSN 0019-9567

Norris, T. \& Bäumler, A. (1999). Phase variation of the lpf operon is a mechanism to evade cross-immunity between Salmonella serotypes. Proceedings of the National Academy of Sciences of the United States of America, Vol. 96, No. 23, pp. 13393-13398, ISSN 0027-8424

Nuccio, S. P. \& Bäumler, A. J. (2007). Evolution of the chaperone/usher assembly pathway: fimbrial classification goes Greek. Microbiology and Molecular Biology Reviews, Vol. 71, No. 4, pp. 551-575, ISSN 1092-2172

Nuccio, S. P., Thomson, N. R., Fookes, M. C. \& Baümler, A. J. (2011). Fimbrial signature arrangements in Salmonella In: Salmonella: from genome to function, S. Porwollick (Ed.), pp. 149-161, Caister Academic Press, ISBN 978-1-904455-73-8, Norfolk

Pan, Q., Zhang, X. L., Wu, H. Y., He, P. W., Wang, F., Zhang, M. S., Hu, J. M., Xia, B. \& Wu, J. (2005). Aptamers that preferentially bind type IVB pili and inhibit human monocytic-cell invasion by Salmonella enterica serovar Typhi. Antimicrobial Agents and Chemotherapy, Vol. 49, No. 10, pp. 4052-4060, ISSN 0066-4804

Pang, T., Levine, M. M., Ivanoff, B., Wain, J. \& Finlay, B. B. (1998). Typhoid fever--important issues still remain. Trends in Microbiology, Vol. 6, No. 4, pp. 131-133, ISSN 0966-842X

Parkhill, J., Dougan, G., James, K. D. \& other authors. (2001). Complete genome sequence of a multiple drug resistant Salmonella enterica serovar Typhi CT18. Nature, Vol. 413, No. 6858, pp. 848-852, ISSN 0028-0836

Parry, C. M., Hien, T. T., Dougan, G., White, N. J. \& Farrar, J. J. (2002). Typhoid fever. New England Journal of Medicine, Vol. 347, No. 22, pp. 1770-1782, ISSN 1533-4406

Paul, K., Erhardt, M., Hirano, T., Blair, D. F. \& Hughes, K. T. (2008). Energy source of flagellar type III secretion. Nature, Vol. 451, No. 7177, pp. 489-492, ISSN 1476-4687

Pickard, D., Li, J., Roberts, M., Maskell, D., Hone, D., Levine, M., Dougan, G. \& Chatfield, S. (1994). Characterization of defined ompR mutants of Salmonella typhi: ompR is involved in the regulation of $\mathrm{Vi}$ polysaccharide expression. Infection and Immunity, Vol. 62, No. 9, pp. 3984-3993, ISSN 0019-9567

Pier, G. B., Grout, M., Zaidi, T., Meluleni, G., Mueschenborn, S. S., Banting, G., Ratcliff, R., Evans, M. J. \& Colledge, W. H. (1998). Salmonella typhi uses CFTR to enter intestinal epithelial cells. Nature, Vol. 393, No. 6680, pp. 79-82, ISSN 0028-0836

Pinkner, J. S., Remaut, H., Buelens, F. \& other authors. (2006). Rationally designed small compounds inhibit pilus biogenesis in uropathogenic bacteria. Proceedings of the National Academy of Sciences of the United States of America, Vol. 103, No. 47, pp. 17897-17902, ISSN 0027-8424

Popoff, M. Y., Bockemühl, J., Brenner, F. W. \& Gheesling, L. L. (2001). Supplement 2000 (no. 44) to the Kauffmann-White scheme. Research in Microbiology, Vol. 152, No. 10, pp. 907-909, ISSN 0923-2508

Prouty, A. M., Schwesinger, W. H. \& Gunn, J. S. (2002). Biofilm formation and interaction with the surfaces of gallstones by Salmonella spp. Infection and Immunity, Vol. 70, No. 5, pp. 2640-2649, ISSN 0019-9567 
Pukatzki, S., McAuley, S. B. \& Miyata, S. T. (2009). The type VI secretion system: translocation of effectors and effector-domains. Current Opinion in Microbiology, Vol. 12, No. 1, pp. 11-17, ISSN 1879-0364

Raetz, C. R. \& Whitfield, C. (2002). Lipopolysaccharide endotoxins. Annual Review of Biochemistry, Vol. 71, pp. 635-700, ISSN 0066-4154

Reeves, P. (1993). Evolution of Salmonella O antigen variation by interspecific gene transfer on a large scale. Trends in Genetics, Vol. 9, No. 1, pp. 17-22, ISSN 0168-9525

Reeves, P. R., Hobbs, M., Valvano, M. A. \& other authors. (1996). Bacterial polysaccharide synthesis and gene nomenclature. Trends in Microbiology, Vol. 4, No. 12, pp. 495-503, ISSN 0966-842X

Robbins, J. D. \& Robbins, J. B. (1984). Reexamination of the protective role of the capsular polysaccharide (Vi antigen) of Salmonella typhi. Journal of Infectious Diseases, Vol. 150, No. 3, pp. 436-449, ISSN 0022-1899

Römling, U., Bokranz, W., Rabsch, W., Zogaj, X., Nimtz, M. \& Tschäpe, H. (2003). Occurrence and regulation of the multicellular morphotype in Salmonella serovars important in human disease. International Journal of Medical Microbiology, Vol. 293, No. 4, pp. 273-285, ISSN 1438-4221

Sabbagh, S. C., Forest, C. G., Lepage, C., Leclerc, J. M. \& Daigle, F. (2010). So similar, yet so different: uncovering distinctive features in the genomes of Salmonella enterica serovars Typhimurium and Typhi. FEMS Microbiology Letters, Vol. 305, No. 1, pp. 113, ISSN 1574-6968

Saini, S., Slauch, J. M., Aldridge, P. D. \& Rao, C. V. (2010). Role of cross talk in regulating the dynamic expression of the flagellar Salmonella pathogenicity island 1 and type 1 fimbrial genes. Journal of Bacteriology, Vol. 192, No. 21, pp. 5767-5777, ISSN 1098-5530

Salih, O., Remaut, H., Waksman, G. \& Orlova, E. V. (2008). Structural analysis of the Saf pilus by electron microscopy and image processing. Journal of Molecular Biology, Vol. 379, No. 1, pp. 174-187, ISSN 1089-8638

Sanowar, S., Singh, P., Pfuetzner, R. A. \& other authors. (2010). Interactions of the transmembrane polymeric rings of the Salmonella enterica serovar Typhimurium type III secretion system. MBio, Vol. 1, No. 3, ISSN 2150-7511

Santander, J., Wanda, S. Y., Nickerson, C. A. \& Curtiss III, R. (2007). Role of RpoS in finetuning the synthesis of $\mathrm{Vi}$ capsular polysaccharide in Salmonella enterica serotype Typhi. Infection and Immunity, Vol. 75, No. 3, pp. 1382-1392, ISSN 0019-9567

Satta, G., Ingianni, L., Muscas, P., Rossolini, A. \& Pompei, R. (1993). The pathogenicity determinants of Salmonella typhi: potential role of fimbrial structures, In: Biology of Salmonella, F. Cabello, C. Hormaeche, P. Mastroeni \& L. Bonina (Eds.), pp. 83-90, Plenum Press, ISBN 0306444925, New York

Sauer, F. G., Pinkner, J. S., Waksman, G. \& Hultgren, S. J. (2002). Chaperone priming of pilus subunits facilitates a topological transition that drives fiber formation. Cell, Vol. 111, No. 4, pp. 543-551, ISSN 0092-8674

Simon, M., Zieg, J., Silverman, M., Mandel, G. \& Doolittle, R. (1980). Phase variation: evolution of a controlling element. Science, Vol. 209, No. 4463, pp. 1370-1374, ISSN 0036-8075

Swietnicki, W., Carmany, D., Retford, M., Guelta, M., Dorsey, R., Bozue, J., Lee, M. S. \& Olson, M. A. (2011). Identification of small-molecule inhibitors of Yersinia pestis Type III secretion system YscN ATPase. PLoS One, Vol. 6, No. 5, p. e19716, ISSN 1932-6203 
Thankavel, K., Shah, A. H., Cohen, M. S., Ikeda, T., Lorenz, R. G., Curtiss III, R. \& Abraham, S. N. (1999). Molecular basis for the enterocyte tropism exhibited by Salmonella typhimurium type 1 fimbriae. Journal of Biological Chemistry, Vol. 274, No. 9, pp. 57975809, ISSN 0021-9258

Townsend, S. M., Kramer, N. E., Edwards, R. \& other authors. (2001). Salmonella enterica serovar Typhi possesses a unique repertoire of fimbrial gene sequences. Infection and Immunity, Vol. 69, No. 5, pp. 2894-2901, ISSN 0019-9567

Tsui, I. S., Yip, C. M., Hackett, J. \& Morris, C. (2003). The type IVB pili of Salmonella enterica serovar Typhi bind to the cystic fibrosis transmembrane conductance regulator. Infection and Immunity, Vol. 71, No. 10, pp. 6049-6050, ISSN 0019-9567

Virlogeux, I., Waxin, H., Ecobichon, C., Lee, J. O. \& Popoff, M. Y. (1996). Characterization of the $r c s A$ and $r c s B$ genes from Salmonella typhi: $r c s B$ through tviA is involved in regulation of Vi antigen synthesis. Journal of Bacteriology, Vol. 178, No. 6, pp. 16911698, ISSN 0021-9193

Wang, F., Zhang, X. L., Zhou, Y., Ye, L., Qi, Z. \& Wu, J. (2005). Type IVB piliated Salmonella typhi enhance IL-6 and NF-kappaB production in human monocytic THP-1 cells through activation of protein kinase C. Immunobiology, Vol. 210, No. 5, pp. 283-293, ISSN 0171-2985

Wang, M., Luo, Z., Du, H., Xu, S., Ni, B., Zhang, H., Sheng, X., Xu, H. \& Huang, X. (2011). Molecular Characterization of a Functional Type VI Secretion System in Salmonella enterica serovar Typhi. Current Microbiology, Vol. 63, No. 1, pp. 22-31, ISSN 1432-0991

Wang, S., Li, Y., Shi, H., Sun, W., Roland, K. L. \& Curtiss III, R. (2011). Comparison of a regulated delayed antigen synthesis system with in vivo-inducible promoters for antigen delivery by live attenuated Salmonella vaccines. Infection and Immunity, Vol. 79, No. 2, pp. 937-949, ISSN 1098-5522

Waterman, S. R. \& Holden, D. W. (2003). Functions and effectors of the Salmonella pathogenicity island 2 type III secretion system. Cellular Microbiology, Vol. 5, No. 8, pp. 501-511, ISSN 1462-5814

Weber, B., Hasic, M., Chen, C., Wai, S. N. \& Milton, D. L. (2009). Type VI secretion modulates quorum sensing and stress response in Vibrio anguillarum. Environmental Microbiology, Vol. 11, No. 12, pp. 3018-3028, ISSN 1462-2920

Weening, E. H., Barker, J. D., Laarakker, M. C., Humphries, A. D., Tsolis, R. M. \& Bäumler, A. J. (2005). The Salmonella enterica serotype Typhimurium $l p f, b c f, s t b, s t c, s t d$, and sth fimbrial operons are required for intestinal persistence in mice. Infection and Immunity, Vol. 73, No. 6, pp. 3358-3366, ISSN 0019-9567

White, A. P., Gibson, D. L., Kim, W., Kay, W. W. \& Surette, M. G. (2006). Thin aggregative fimbriae and cellulose enhance long-term survival and persistence of Salmonella. Journal of Bacteriology, Vol. 188, No. 9, pp. 3219-3227, ISSN 0021-9193

Wilson, R. P., Winter, S. E., Spees, A. M. \& other authors. (2011). The Vi capsular polysaccharide prevents complement receptor 3-mediated clearance of Salmonella enterica serotype Typhi. Infection and Immunity, Vol. 79, No. 2, pp. 830-837, ISSN 1098-5522

Winter, S. E., Raffatellu, M., Wilson, R. P., Rüssmann, H. \& Bäumler, A. J. (2008). The Salmonella enterica serotype Typhi regulator TviA reduces interleukin-8 production in intestinal epithelial cells by repressing flagellin secretion. Cellular Microbiology, Vol. 10, No. 1, pp. 247-261, ISSN 1462-5822 
World Health Organization, Department of Vaccines and Biologicals. (May 2003). Background document: the diagnosis, prevention and treatment of typhoid fever. Geneva, Switzerland, pp. 1-38. Available from www.who.int/entity/vaccine_research/documents/en/typhoid_diagnosis.pdf.

Yu, X. J., Liu, M. \& Holden, D. W. (2004). SsaM and SpiC interact and regulate secretion of Salmonella pathogenicity island 2 type III secretion system effectors and translocators. Molecular Microbiology, Vol. 54, No. 3, pp. 604-619, ISSN 0950-382X

Zavialov, A. V., Kersley, J., Korpela, T., Zav'yalov, V. P., MacIntyre, S. \& Knight, S. D. (2002). Donor strand complementation mechanism in the biogenesis of non-pilus systems. Molecular Microbiology, Vol. 45, No. 4, pp. 983-995, ISSN 0950-382X

Zenk, S. F., Jantsch, J. \& Hensel, M. (2009). Role of Salmonella enterica lipopolysaccharide in activation of dendritic cell functions and bacterial containment. Journal of Immunology, Vol. 183, No. 4, pp. 2697-2707, ISSN 1550-6606

Zhang, X. L., Tsui, I. S., Yip, C. M., Fung, A. W., Wong, D. K., Dai, X., Yang, Y., Hackett, J. \& Morris, C. (2000). Salmonella enterica serovar Typhi uses type IVB pili to enter human intestinal epithelial cells. Infection and Immunity, Vol. 68, No. 6, pp. 30673073, ISSN 0019-9567

Zhao, L., Ezak, T., Li, Z. Y., Kawamura, Y., Hirose, K. \& Watanabe, H. (2001). Vi-Suppressed wild strain Salmonella typhi cultured in high osmolarity is hyperinvasive toward epithelial cells and destructive of Peyer's patches. Microbiology and Immunology, Vol. 45, No. 2, pp. 149-158, ISSN 0385-5600

Zhao, Y., Jansen, R., Gaastra, W., Arkesteijn, G., van der Zeijst, B. A. \& van Putten, J. P. (2002). Identification of genes affecting Salmonella enterica serovar Enteritidis infection of chicken macrophages. Infection and Immunity, Vol. 70, No. 9, pp. 53195321, ISSN 0019-9567

Zogaj, X., Nimtz, M., Rohde, M., Bokranz, W. \& Römling, U. (2001). The multicellular morphotypes of Salmonella typhimurium and Escherichia coli produce cellulose as the second component of the extracellular matrix. Molecular Microbiology, Vol. 39, No. 6, pp. 1452-1463, ISSN 0950-382X 
(C) 2012 The Author(s). Licensee IntechOpen. This is an open access article distributed under the terms of the Creative Commons Attribution 3.0 License, which permits unrestricted use, distribution, and reproduction in any medium, provided the original work is properly cited. 